\title{
3 \\ Origins of the Amherst Embassy: Canton and Sir George Thomas Staunton
}

Historians have traditionally assessed Sir George Thomas Staunton's importance in the Amherst Embassy within the narrow context of his advice to Amherst to not kowtow before the Jiaqing emperor. While this advice was critical to the outcome of the embassy, Staunton's very significant role in the 16-year period leading eventually to the decision to dispatch an embassy in 1816 has been largely overlooked. Reference to Staunton's private letters written to his parents during his time as a servant of the Company at Canton from 1800 to 1817 provides a firsthand account of the specific conditions at Canton under which trade was conducted, as well as his role in the British decision to dispatch an embassy to the Qing court in 1816 . Staunton, it will be seen, was a highly motivated individual who was determined to live up to the high expectations of his parents and mentors, namely, Lord Macartney and John Barrow. His shyness, social ineptness and intense dislike of the boisterous drinking culture of the British Factory, notable at the time of his early years at Canton, resulted in his taking refuge in the study of Chinese law, literature and Mandarin. Staunton's importance for the Amherst Embassy is traced in this chapter on a number of levels, dating from the time of his arrival at Canton as a junior writer with the Company, until his final departure from Canton in January 1817 as president of the Select Committee following the conclusion of the Amherst Embassy. 


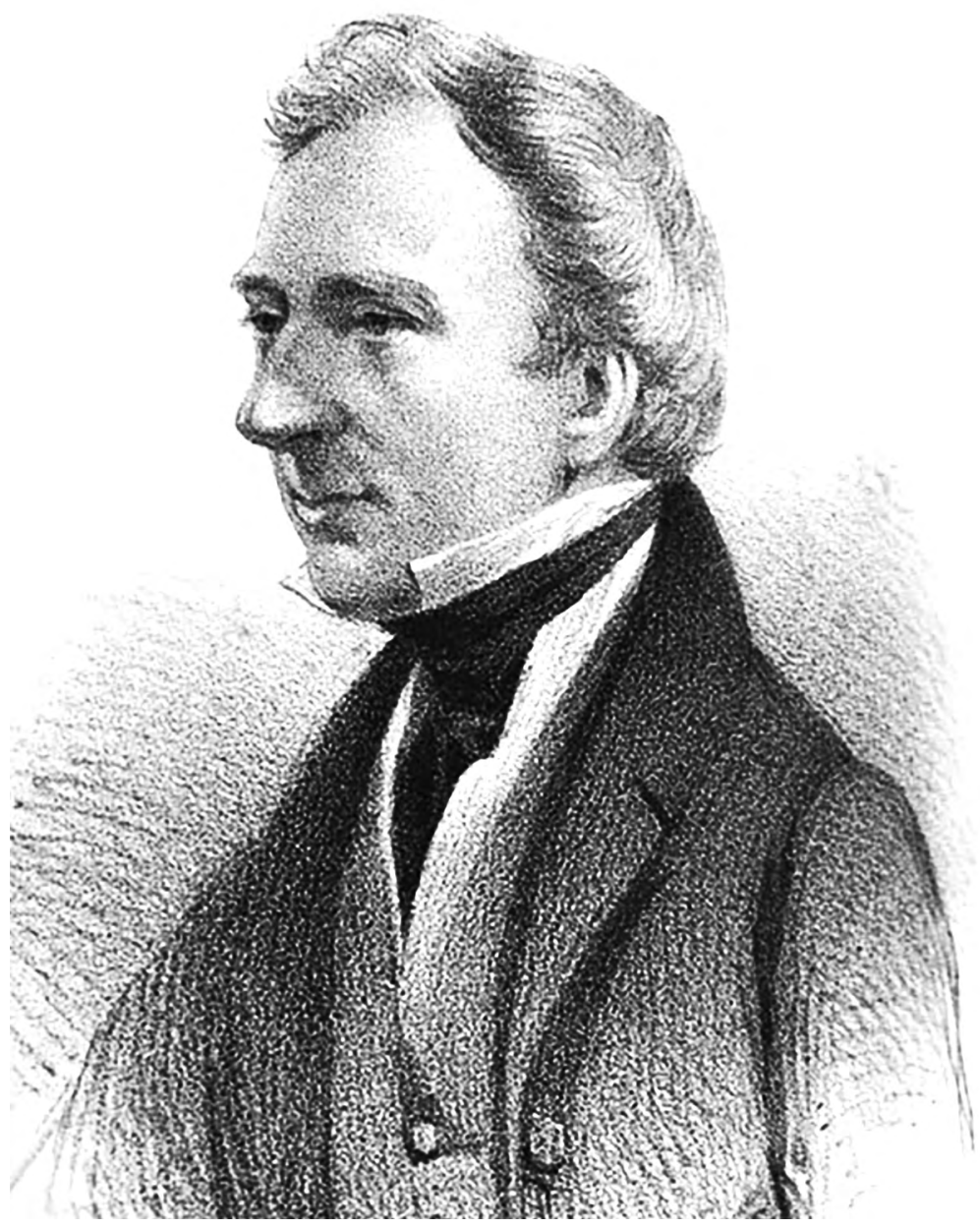

Figure 4: Portrait of Sir George Thomas Staunton at 52 years of age.

Note: Engraving after painting by Sir George Hayer in 1833.

Source: LibraryThing (www.librarything.com/gallery/author/stauntonsirgeorge).

First and significantly, Staunton exerted a strong influence on the views of his friend and mentor John Barrow, the second secretary to the Admiralty, who was the man most responsible in 1815 for advocating the need for an embassy to the Qing court. Staunton corresponded regularly with Barrow on the desirability of a follow-up to Macartney's Embassy and provided him with both reports and assessments to support this view. Second, Barrow thought that Staunton's unique knowledge of China, command 
of the Chinese language and experience in dealing with local officials at Canton was the key to a successful mission to the Qing court where the Macartney Embassy had been lacking and consequently failed. Moreover, Staunton enjoyed a reputation as Britain's leading sinologist with the publication in 1810 of his translation of the Chinese penal code under the title Ta Tsing Leu Lee. Third, Staunton exploited his unique position at Canton to acquire information on the Qing court that was denied to other Westerners. His systematic intelligence collection came from several sources including high-ranking mandarins, Hong merchants and Catholic missionaries based at Peking, as well as official Chinese publications originating in Peking. Taken together, these uniquely informed Staunton, who in turn informed Barrow of an embassy's prospects at the Qing court and revealed the state of British knowledge of Chinese attitudes to foreigners in the period before the Amherst Embassy. Finally, Staunton's great personal ambition, apart from making a substantial fortune at Canton, was to return to Peking in some capacity with a British embassy, preferably as its leader. To expedite his chances, Staunton drew up plans for another embassy, namely, in 1800-1801 and 1809-1810. Both plans were dismissed by the Court of Directors of the Company, for reasons that will be discussed in the first part of this chapter, who preferred to let matters rest with the status quo. The second part of the chapter focuses on the disputes at Canton in the immediate period of 1812-1814, where Staunton played a pivotal role and the Court of Directors finally became convinced of the need to finance an embassy to Peking.

\section{George Thomas Staunton (1781-1859)}

George Thomas Staunton was born at Salisbury on 26 May 1781. His father, Sir George Leonard Staunton, had left England in January of that year accompanying Lord Macartney on his posting as governor of Madras and did not see his son until his return to England in $1784 .{ }^{1}$ The boy's education and welfare, Staunton wrote later, became the 'the master purpose of my father's mind' (1856, p. 3). Staunton was educated at home in the classics and sciences and spoke to his father only in Latin.

1 Sir G. L. Staunton was appointed Macartney's secretary in 1780, proceeded to India at the time of Macartney's appointment as governor of Madras and, while there, negotiated a peace settlement with the Tipu Sultan of Mysore that ended the Second Anglo-Mysore War in India (see CranmerByng, 1962, p. 307; Eastberg, 2009, pp. 26-37). 
The Percy anecdotes (Vol. 3) referred in 1826 to the young Staunton at the time of the Macartney Embassy's return voyage from China to England in 1794 where the boy:

was on the deck of the Lion with his father ... who imagining that a French man of war was going to engage them, desired his son in Latin ... to go down below deck. 'Mi Pater, nunquam te desseram'. 'My father, I will never forsake you', was the spirited and affectionate reply. (p. 112)

One of Staunton's tutors during the Macartney Embassy (1792-1794) was John Barrow, who had been appointed the comptroller in charge of the presents sent by George III to the Qianlong emperor, on the recommendation of Staunton's father (Staunton, 1856, p. 9).

Participation in the Macartney Embassy defined the careers of not only Barrow, but also of Sir George and his son. ${ }^{2}$ Staunton senior had hoped to remain in Peking as the resident minister for England after the departure of the embassy, but had to return to England at the time of its premature dismissal from Peking. An opportunity to return to Peking as the minister plenipotentiary in a proposed embassy to China in 1796 following the Qianlong emperor's invitation for another British mission to visit Peking was shelved after Staunton senior suffered a 'paralytic seizure' (Staunton, 1856, p. 16). Similarly, as noted above, Staunton became a widely known celebrity as the boy who spoke to the Qianlong emperor in Mandarin and received a gift of a small golden silk purse from the emperor's own hands (G. L. Staunton, 1797b, p. 348).

Young George Staunton entered Trinity College, Cambridge, at age 16 to read 'Arts and Manufactures' under Professor Farish. He lived off campus with his parents and mixed socially with senior academics, rather than with students of his own age. ${ }^{3}$ However, Staunton senior withdrew his son from the university after only two terms in protest when he was awarded with the second, and not the first prize, in the first-year examinations. The family, while moderately wealthy and possessing landed estates in Ireland, did not have the financial resources for young Staunton to pursue an independent lifestyle befitting his station. His father, Staunton wrote,

2 Sir G. L. Staunton's (1797a) book was acknowledged as the official account of the embassy.

3 Staunton spent his summer holidays with his cousins, the children of the Reverend and Mrs Brodie, near Salisbury, just before he entered Cambridge. He wrote that this was a most enjoyable time and represented the only occasion where his father 'allowed me of freely associating with young persons of about my own age' (Staunton, 1856, p. 19). 
now thought that 'an appointment in the service of the Company might still enable me to follow up my early introduction to Chinese diplomacy, and to acquire honour and distinction in that career' (Staunton, 1856, p. 17). Staunton's great ambition to lead another British embassy to China, doubtless influenced by his father's ambitions for him, was formed at this time.

Staunton's application to join the Company ranks was not a straightforward process. His appointment as a junior writer was secured only after some intense lobbying by both Macartney and Sir George promoting his cause as the only Englishman who knew Mandarin. The appointment was very unpopular within the Company and drew criticisms of 'undue interference with private patronage' as the lucrative post of writer was reserved traditionally for the sons and relatives of Company Directors (Staunton, 1856, p. 17). The position paid $£ 2,000$ a year (equivalent to approximately $£ 200,000$ in today's values), yet Staunton found this barely enough to cover daily living expenses at Canton and Macao, and he sought extra funds from his parents to provide loans on high interest to Hong merchants. ${ }^{4}$

Staunton embarked on the Indiaman, Hindostan, for the six-month journey to China on 18 June 1799. His father wrote to him the next day:

I still believe that I have fallen upon the best, or at least the most likely, means of providing for your future happiness, but it is not the most happy for me to be thus separated from you ... but you will finally return [from China] I hope, with a competent fortune. (Staunton, 1856, p. 23)

Staunton arrived in China in January 1800 and discovered that his fame as the 12-year-old English boy who had held a brief conversation with the Qianlong emperor at the time of the Macartney Embassy had gone before him. He was visited immediately on landing at Macao by Father Marchini, the chief cleric in charge of the Roman Catholic Mission. ${ }^{5}$ Marchini, recently returned from Peking, remembered speaking to Staunton in Mandarin in 1793 (Staunton Letters, Macao, 20 January 1800). Staunton

4 Staunton wrote in his memoirs (1856) of a salary increase from $£ 2,000$ as a writer to $£ 10,000$ on promotion to a supercargo in 1804 (pp. 32-33). See fn. 31 of this chapter for further information on Staunton's loans to Hong merchants.

5 Staunton (1822, p. 81) recorded that John Baptist Marchini, was a 'highly esteemed and venerated ecclesiastic' whose 'liberal conduct and conciliating manners have gained him the general esteem of the Europeans in China'. 
was also visited by two leading Hong merchants, Puankhequa and Chung Qua, on arrival at Canton. ${ }^{6}$ Such a visit to the most junior member of the British Factory was unprecedented but, as Staunton told his parents, they 'knew of my speaking Chinese and one of them [Chung Qua] conversed with me in Chinese for half an hour' (Staunton Letters, Canton, 25 January 1800). Another mandarin of 'considerable rank', whose name is not known, also invited Staunton and the Company doctor to visit him using the pretext of attaining a consultation for an eye complaint. The mandarin, Staunton wrote, received them with:

great complacency and good nature and addressing himself to me in Chinese declared that he recollected very well to have seen me when the Embassy was at Pekin and eagerly asked in return whether I did not recollect him also, which from civility I could not absolutely deny though I did not retain any remembrance of him, or was it likely that I should. During dinner he enquired after the health of the first Embassador and of the Second Commissioner $\ldots$ and where they resided and what stations they now filled in their Native country. (Staunton Letters, Macao, 26 May 1800)

Staunton enjoyed few other social occasions at Canton. At just 19 he held not only the most junior position at the British Factory but was also the youngest member among his 13 compatriots. His singular upbringing and previous life in England ill-prepared him for the society of an all-male expatriate culture of heavy drinking sessions and boisterous behaviour and he recorded in his memoirs that his first two years at Canton were 'the most gloomy period of my life' (Staunton, 1856, p. 25). 'I was singularly unprepared', he wrote, 'for those collisions which must always tend a youth's first initiation in mixed society' (Staunton, 1856, p. 25). He told his parents at the time that '[I] felt the greatest stranger amongst them' and was 'pretty well guarded against the temptations of the Canton table' (Staunton Letters, Macao, 12 May 1800). Fortunately for British sinology, Staunton devoted his leisure time at the British Factory to studying Mandarin and Chinese literature.

6 The former is likely to be, in Van Dyke's (2011) romanisation, Poankeequa II (Pan Youdu). The latter, likely to be Conqua in Van Dyke's (2011) romanisation, is more difficult to identify. For a discussion on possible people see Van Dyke (2011, pp. 325-362). 
Propitiously, Staunton had arrived at Canton at the time of a major legal dispute between the Select Committee and local government. Known as the Providence affair, it concerned a Chinese boatman who had drowned while attempting to cut the cable and steal the anchor of a British ship moored at Whampoa. The subsequent demand by the Chinese authorities for the handover of the British sailor who had fired under orders over the head of the would-be thieves, thus causing the victim to jump overboard and drown, was rejected by the Select Committee. Staunton was engaged by the Company to interpret at the ensuing trial held before the senior mandarins, Hong merchants and Company Select Committee. His Mandarin skills, he modestly informed his parents, were 'wholly unequal' to the task. Nevertheless, the occasion provided an unprecedented opportunity for Staunton's involvement in composing personal and written communications in Mandarin to the Chinese Government (Staunton Letters, Macao, 25 September 1800).

Staunton's experience at the Providence trial revealed how a mastery in the language could gain access to high-ranking government officials. The viceroy, Staunton informed his parents, took the singular opportunity of visiting the British Factory without the Hong merchants, as 'he was sufficiently familiar with my foreign pronunciation' and did not need the aid of a Hong linguist (Staunton Letters, Macao, 27 March 1800). The president of the Select Committee, Richard Hall, informed Staunton that this was 'the only instance of direct communication with the Chinese government without the interference of the merchants' and, if continued, would prove 'a considerable check' on their behaviour, removing the need of 'exclusively confiding ... in native linguists, who might be corrupted or intimidated' (Staunton Letters, Macao, 26 May 1800). ${ }^{7}$ His participation at the trial, however, had a significant downside. Staunton wrote that it:

in great measure indisposed the Hong Merchants towards me, who are sufficiently aware of the checks upon their conduct that my acquaintance with the language of the country, may hereafter become. (Staunton Letters, Canton, 27 March 1800)

7 The need for accurate communication between the Select Committee and Chinese authorities remained throughout this period. In 1805, the committee wrote on the matter of interpreting and translating communiques reliant on Chinese linguists who knew only 'pidgin' English: 'The difficulty in obtaining a faithful interpretation of a letter by means of the Merchants is almost insurmountable, it being only by general expressions that we can at any time render ourselves intelligible' (Morse, 1926/1966, vol. 3, p. 7). 
Staunton was certainly motivated to pursue his studies in Mandarin following Hall's praise, if only to enhance his Company career. ${ }^{8}$ His main aim, however, was to prepare himself in the event of another British embassy being sent to the Qing court. This remained his burning ambition until he finally abandoned the idea around 1812 . He told his parents in 1800 that 'the principal advantage [of knowing Mandarin] which I look to is what you so frequently foretold, that of the event of another Embassy to this country'. This, he added, was 'frequently in my thoughts' (Staunton Letters, Canton, 15 November 1800). The praise he received following his participation in the Providence affair suggested to him that:

my acquaintance with the Chinese gives me some chance of being called upon to accompany such an expedition [and] I cannot help fancying some connection with it ... I have been so fortunate as to have met with opportunities of giving proof of my acquaintance with the Chinese language, and that the Chief [Hall] has been so good as to record them ... I do not give up the expectation that if an Embassy were appointed some mentions could be made of me in some shape or other. (Staunton Letters, Macao, 26 May 1800)

Staunton set out to collect information on the Qing court to prepare himself for future diplomatic service. He learned a vital piece of intelligence from Marchini, who informed him of a significant change in the imperial attitude towards Westerners: 'The new [Jiaqing] Emperor', Staunton was told, 'is said to be more favourably inclined to the Europeans than his predecessor' (Staunton Letters, Macao, 20 January 1800). This represented a promising change in the attitude of the Chinese Government exemplified locally at Canton by:

The kindness and humanity of the present Viceroy ... frequently shown to foreigners, [which] makes it reasonable to express that he would in some degree co-operate in the wishes of an Embassador or at least not prove an obstacle to the success of his measures. (Staunton Letters, Macao, 26 May 1800)

Further consultations with 'some intelligent Chinese' confirmed Staunton's growing belief that another British embassy to China 'would be met with a favourable reception' (Staunton Letters, Macao, 18 August 1800).

8 Staunton hoped Hall would advance his case for a further increase in his salary based on his proficiency in Mandarin, but the directors in London did not approve any compensation, much to his dismay (Staunton Letters, Canton, 9 January 1801). 
Staunton also sought to cultivate the views of foreign missionaries based in Peking. Commenting on a letter he had received from the Vincentian priest, Louis Lamiot, Staunton told his parents:

Lamiot seems to be a man of information and I shall cultivate his acquaintance by letter and newspapers which I hope to send to him by means of Portuguese Missionaries who are now at Canton and waiting for the Emperor's orders for them to proceed to Peking. (Staunton Letters, Canton, 9 January 1801) ${ }^{9}$

Staunton's intention was clear, namely, to ascertain 'the present disposition of the Court towards foreigners and what alteration the death of the late Minister [Heshen] and the succession of the present Emperor had made in the Government' (Staunton Letters, Canton, 26 February 1801). ${ }^{10}$ He had high hopes that the Portuguese missionaries waiting at Macao for permission to travel to Peking would prove useful informants and sought to ingratiate himself by presenting them with newspapers and books recently received from India, to 'incline them to make me that kind of return which circumstances may put in their power' (Staunton Letters, Canton, 26 February 1801). A meeting with the missionaries proved disappointing. Staunton found they had neither 'the talents or capacity' to carry much weight at Peking and possessed little ability to 'exert any pressure' on behalf of the British people at the Qing court (Staunton Letters, Canton, 5 March 1801). ${ }^{11}$ Father Lamiot, on the other hand, continued to write letters to Staunton and his views informed the assessments that were later passed to Amherst during his preparations for the embassy.

Staunton's major source of intelligence on the Qing court was the weekly Chinese Government publication, referred to by the British as the Peking Gazette, which arrived at Canton every four or five days. The Gazette,

9 Lamiot arrived in China at the end of 1793 and later served in the Secretariat at the Qing court as an interpreter, translating Chinese documents into Latin and sending them to Russia. He left Peking in 1819 and died at Macao (Fu, 1966, vol. 1, p. 327; 1966, vol. 2, p. 583).

10 The reference to Minister Heshen reflects the British view that he had played an important role in disposing the Qianlong emperor to refuse a dialogue with Macartney on British goals. Heshen was arrested by the Jiaqing emperor and his assets seized, acquired it was thought, through corruption and the favouritism of his father. Heshen was 'given Imperial permission to commit suicide' (CranmerByng, 1962, pp. 321, 322).

11 Fu (1966, vol. 2, p. 591, fn. 25-26) documented that three Western missionaries were granted permission to travel to Peking at this time; namely, a Portuguese Lazarist appointed to the Board of Astronomy in December in 1801 and who died in 1823; Joseph Nunez Ribeiro; and Gaetan PiresPireira, who was sick and remained in Canton. 
written in the 'court style', contained 'very curious information' found in imperial edicts and petitions giving 'insight into the policy of the Government' (Staunton Letters, Macao, 5 August and 9 August 1801). ${ }^{12}$ The Chinese press, Staunton complained, while free of government censorship, focused mainly on literary forms rather than current political issues (Staunton, 1810, p. xii). He wrote later that the Gazette's prime function was to influence and conciliate public opinion upon all state questions, which under a government theoretically so despotic, would hardly have been expected' (Staunton, 1821, p. xxi).

The Select Committee, meanwhile, sent copies of Staunton's translations of the Gazette to India following the request of the editor of the Bombay Courier. These, in turn, were passed directly to Governor-General Lord Wellesley. Staunton's linguistic skills had made it possible to transmit hitherto unavailable intelligence on the Qing court to British recipients throughout the region.

A major consequence of Staunton's involvement at the Providence trial was his discovery of the printed penal laws of China, which the Company proceeded to purchase on his behalf. ${ }^{13}$ Staunton began translating these into English in late 1800 to assist the Company's understanding of Chinese law and its application. Their publication in 1810, under the title Ta Tsing Leu Lee, represented the first direct English translation of a Chinese text and firmly established Staunton as Britain's leading sinologist. ${ }^{14}$

\section{Staunton's First Plan for Another British Embassy, 1800}

Staunton drew up his first plan for another embassy to the Qing court in 1800. He focused on the important role of royal letters in Qing diplomacy and advocated that George III send an annual letter with a British

12 Staunton learned of the serious rebellions taking place in northern China in 1801, but was sceptical of government claims of victory after witnessing the number of troops mobilising on the river at Canton. This proved, he wrote, 'how little effect these victories have had in the pacification of the Provinces'.

13 Copies of the Penal Code were provided by the viceroy. Staunton also acquired a 24-volume set and 144-volume set of the code between March and November 1800 (Staunton Letters, Canton, 27 March and 8 November, 1800).

14 Staunton thought that while China's penal laws were 'not the most just and equitable', they were 'the most comprehensive, uniform, and suited to the genius of the people for whom [they were] designed, perhaps of any that ever existed' (Staunton, 1810, p. xi). 
ambassador to the Jiaqing emperor with the first ships of the season, followed by the emperor's reply carried by the last ships. He thought that, given the distance between Britain and China, there would be no objection to a 'perpetual residence' being established at Peking. Such a privilege, he was aware, was denied to all the 'petty surrounding states who sent annual Ambassadors to the Court of Pekin from time immemorial', and who were seen by the Chinese as 'barbarians', but he felt an exception would be made for the British based on the fact of:

The grandeur and respectability with which the former [Macartney] Embassy appeared at the Court of Pekin would prevent any future Ambassador from being degraded to the rank of messengers from tributary and subordinate states though he should annually attend with them at the Emperor's court. (Staunton Letters, Canton, 26 February 1801)

A similar assessment is found in Macartney's account, which refers to the Jesuit Father Amiot's view. While acknowledging that the Chinese had been alarmed on learning of news of war in Europe, Amiot assured Macartney that '[His] Embassy had been so brilliant, and ha[d] made such an impression in the country, as must in the end be productive of very happy consequences'. Further, Amiot advised that 'the ground gained by sending an Embassy from the King to the Emperor should by no means be lost, but be followed up by an intercourse of letters between them' (Cranmer-Byng, 1962, p. 151).

This view echoed those of Staunton senior, who wrote of the exceptional circumstances of Macartney's reception at the Qing court:

The dignified and splendid manner in which the Embassy was received, influenced the minds of the Chinese, and induced them to believe that the government was about to make a change of measures favourable to the English. Embassadors were not usually received by the Emperor upon his throne; nor were their credentials delivered into his hands, but ordinarily into those of his ministers. (G. L. Staunton, 1797b, vol. 2, p. 347).

Macartney's legacy, especially being permitted to hand his credentials and the king's letters into the emperor's own hands and performing the British ceremony of bowing on one knee rather than the kowtow, persisted as the major flaw in British assessments of their likely reception by the Jiaqing emperor and represented a fundamental misunderstanding of Qing court protocol that lies at the core of Amherst's failure. Staunton's unwavering 
belief in the impact of the Macartney Embassy's splendid appearance and civility of manners in contrast to those of China's traditional vassal states is understandable if misplaced. His opinion, accepted unconditionally by Barrow, that the Qing court would make an exception for a British embassy and would receive it outside the framework of the traditional tribute system, was both a major factor in favour of sending a second embassy in 1816 and a key reason for its failure. Macartney's dispensation of not having to perform the kowtow before the Qianlong emperor resulted in the Jiaqing emperor being resolute in insisting on its performance. It is ironic, therefore, that the prime legacy of the Macartney Embassy for the outcome of the Amherst mission was to make the emperor determined that Amherst comply fully with the court ceremony that lay at the core of the tribute system.

The Company Directors in London did not share Staunton's enthusiasm for another embassy. No arrangements were made for a letter from George III congratulating the Jiaqing emperor on his accession to the throne and a disappointed Staunton told his parents:

I am sorry to find how little disposed the Minds of the Directors and of others in power are to the idea of a second Embassy ... one of the Directors thought it best to 'Let the Government of China alone'. (Staunton Letters, Canton, 26 February 1801)

Nevertheless, Staunton persisted with the hope of returning to Peking and turned his attention to learning the 'Mantokoo Tartar' language spoken at the Qing court (Staunton Letters, Canton, 26 February 1801). Fluency in the Manchu language, Staunton thought, would be very useful at Peking as it would enable a direct dialogue with the emperor in his native tongue. His assumption that the Jiaqing emperor would be open to personal conversation and negotiation, most likely founded on his boyhood experience of conversing with the Qianlong emperor in 1793, may be read as understandable but misguided, as events later proved. 


\section{Staunton Back in England, 1803-1804}

Staunton was on leave in London during 1803-1804, having returned to England upon learning of his father's death. ${ }^{15} \mathrm{He}$ spent his time staying with Lord Macartney and his family, as well as with John Barrow who had recently been appointed second secretary to the Admiralty. ${ }^{16}$ Barrow, no doubt prompted by Staunton, raised the matter of another embassy to China with the Company Directors. Their response remained 'cold and indifferent', although they did agree to send a letter from George III and gifts valued at $£ 2,176$ to the Jiaqing emperor to placate him over British military actions at Macao in 1802 (Fu, 1966, vol. 2, p. 595, fn. 51). ${ }^{17}$

Staunton still harboured hopes of being involved in another embassy and appearances were important. He wrote to his mother from Portsmouth on the eve of sailing for China, 'I have just complied with your wishes in having my hair cut ... and henceforth shall leave off the powder' (Staunton Letters, Portsmouth, 31 May 1804). ${ }^{18}$ His decision may be read as representing a historic change from the men of Georgian England, who, like the men of the Macartney Embassy, dressed in powdered wigs, tight silk britches and stockings. Dress for gentlemen at the beginning of the nineteenth century consisted of a more casual attire of tailored trousers, jackets and top hats. ${ }^{19}$ Staunton added:

15 Sir G. L. Staunton died on 14 January 1801. News of his death reached Staunton in late August 1801 and was referred to as a 'melancholy catastrophe' (Staunton Letters, Macao, 28 August 1801). Staunton started planning his return to England with the first fleet to sail from China. Leave approval in London was secured through the efforts of Lord Macartney who convinced the Company Directors to allow Staunton to return. Staunton planned to take two Chinese Christian missionaries with him at his own expense for 'the benefit of pursuing my Chinese studies' on the passage to England to show the directors that he was not neglecting his duty to the Company (Staunton Letters, Macao, 3 October 1801). Staunton inherited his father's estate, apart from a small legacy left to his mother. He also succeeded to the Baronetcy.

16 Macartney pledged to take 'the place' of his father in promoting Staunton's interests. He presented him at court before George III and Queen Charlotte in December 1802 and was instrumental in having him elected at the Literary Club as well as the Royal Society (Staunton, 1856, p. 31).

17 George III's letter was dated 22 May 1804.

18 British attitudes to the use of hair powder by men had changed by the beginning of the nineteenth century. Seen previously as a badge of gentlemanly respectability, hair powder was now perceived as effeminate and indicative of the corrupting effects of modern commercialism that had taken place in Britain in the eighteenth century. Its use, still prominent among French emigres, was considered representative of dandyism and 'the irresponsible frivolity of the ancient regime' (see Barrell, 2006).

19 The mode of dressing fashionable among the British supercargoes at Canton is revealed in the oil painting by a Chinese artist of the trial of the Neptune's seamen in 1807 (reproduced in Conner, 2009, pp. 68-69). 
As improbable things sometimes happen, Mr. Barrow's expectations of an Embassy may one day be realised - upon such an event you must judge what clothes etc, etc, may be fit to send me out upon such an occasion. (Staunton Letters, Portsmouth, 31 May 1804)

Staunton sent his mother another letter on arrival at St Helena, illustrating his confidence in the opinions of his two patrons:

The etc, etc, which I expressed a desire might be sent me in the event of an Embassy, did not imply anything in particular, but I only wished that under such circumstances, anything really new, curious or useful, which might be suggested by my uncle [Macartney] or Mr. Barrow should not be rejected in order to save a little expense. (Staunton Letters, St Helena, 9 June 1804)

Curiously, the route to China went via Norfolk Island. Staunton told his mother:

We have taken an unusual and circuitous route. The name of the remote spot ... will be familiar to you, from the circumstance of its having been the former residence of Governor and Mrs. King, who are still I believe at Port Jackson which is in the neighbourhood. (Staunton Letters, Staunton to his mother, written near Norfolk Island, 9 November 1804 but sent from Canton, 18 January 1805)

General letters for England were deposited at the time with two Botany Bay ships on their way to England (Staunton Letters, Canton, 24 February 1805). ${ }^{20}$

\section{Staunton Returns to China, 1805}

Staunton was promoted to the rank of supercargo on his return to the British Factory at Canton and enjoyed a substantial increase in salary from $£ 2,000$ to $£ 10,000$ per annum (Staunton, 1856, p. 32). Immediately upon his return, he was called on to attend the viceroy's palace to witness the Company's formal acceptance of a letter and presents from the emperor to George III, which had been sent in response to the king's letter and presents received in 1805 (Fu, 1966, vol. 1, p. 349). The king had endeavoured to reassure the emperor that the presence of six British warships off Macao in 1802 did not constitute a military threat, 
as rumoured by the Portuguese and French, but sought only to protect British trade. Similarly, an explanation was given also for the presence of other British warships in Chinese waters required to convoy the Indiamen to protect them from French attack.

Permission to enter the city of Canton and a formal call on the viceroy at this time represented a rare opportunity for the British. They made their 'bows in the viceroy's palace' and received presents for the king consisting of teas, silks and porcelains. ${ }^{21}$ Morse (1926/1966, vol. 3, p. 29) records:

It had been previously ascertained that the Mandarines were to deliver the Imperial Letter standing, and that on receiving it no more would be required from [the British] than an obeisance conformably to the usages of Europe.

The viceroy, however, informed the emperor that the British had kowtowed, which they read as an indication of his fear of incurring the emperor's displeasure on learning the truth. The emperor's letter confirmed that another British embassy would be received strictly within the context of the traditional tribute system. It contained language read by the British as condescending, which referred to them as 'Strangers' who being 'awed by Our power, Nobly ... bring their tributes from remote distances and throng to do homage to Our Empire'. Further:

Your kingdom is far distant and separated from Us by the seas, yet you respectfully observe the duties of a vassal state. From a remote region, you manifest your loyalty toward the Sun [the emperor]. (as quoted in $\mathrm{Fu}, 1966$, vol. 1, p. 361)

George III was informed that if the British:

Continue to offer amity and friendship as an ally, if you can lead all your subjects to present tribute and serve Us as our vassals, then you will fulfil Our sublime principle of loving strangers and extending our benevolence to them. (as quoted in $\mathrm{Fu}, 1966$, vol. 1, p. 361)

21 The presents consisted of 'fourteen suitcases which contained six rolls of silk ... four porcelain vases, four porcelain plates, eight porcelain bowls and eight porcelain dishes, four boxes of spring tea, and four rolls of the P'u-er tea' (Fu, 1966, vol. 1, p. 367). 
Regardless of the compromise made at the time of Macartney over the kowtow, the Jiaqing emperor made it clear that a future British embassy would receive no such dispensation. Prospects for a successful negotiation of British goals remained as remote as ever.

Staunton's hitherto favourable impression of the local government changed further with the arrival at Canton of a new viceroy who was ill-disposed and unfriendly to the British. He wrote contemptuously of 'the many instances I have witnessed lately of the pride, weakness and corruption of the Chinese government' (Staunton Letters, Canton, 5 November 1805). Dispirited, Staunton concluded in 1805 that the chances of a successful British mission to Peking 'are fewer and those of failure more numerous than I had anticipated'. He added:

I am satisfied indeed that the success of any Mission to the Court of Pekin, must be very limited and precarious, but it is much easier now to satisfy the expectations of ministers and the Public [in England] than it was at the time of the former Embassy, since the flattering but groundless calculation of success which then existed are at present totally relinquished and the World is sufficiently acquainted with the Pride, meanness and ignorance which characterizes the Court of Pekin, which must obstruct the views of a Negotiator, publish the disgrace of his failure, and enhance the Men of [any] success. (Staunton Letters, Canton, 30 December 1805)

Despite the belief that the Macartney Embassy had deeply impressed its hosts, Staunton suggests that the expectations of the British public were more realistic following the popularity of Barrow's scathing account of China published in 1804. News of a failed Russian embassy sent to the Jiaqing emperor in 1805-1806, where the ambassador Count Golovkin was expelled from China for refusing to kowtow, reached Staunton late in 1806. His faith in a more positive reception for any future British ambassador was restored. Staunton asked his mother:

Please inform my good friend Mr. Barrow ... [that] the Emperor of China has been more polite to his brother the King of England having written him a civil letter and transmitted some presents. (Staunton Letters, Canton, 16 December 1806) ${ }^{22}$

22 The significance of the Golovkin Embassy for the Amherst Embassy is discussed later in this study. 


\section{Staunton's Second Plan for a British Embassy to the Jiaqing Emperor, 1810}

Staunton returned to England on leave in 1808 following a serious dispute at Canton where trade was stopped over a fracas between local Chinese and British sailors. ${ }^{23} \mathrm{He}$ was absent also from China at the time of the second British occupation of Macao but, on learning the news in London, he joined with Barrow to lobby the Company Directors for an embassy to the Jiaqing emperor to repair relations (Morse, 1926/1966, vol. 3, pp. 79-99). ${ }^{24}$

The directors received Staunton's plan for another British embassy on 20 November 1809 (Staunton Letters, London, 20 November 1809). ${ }^{25}$ Staunton again emphasised the importance of a formal letter sent from George III to the emperor informing him specifically of his strong desire for amicable and beneficial relations, and notifying him that the occupation of Macao by British troops was not authorised nor approved by the British Government. The inclusion of Mandarin translations of British Government documents would serve to convince the emperor of British integrity, thereby disposing him to encourage the viceroy at Canton to remove all trade restrictions imposed on the Company.

In a reference to himself and representing a new proposal, Staunton argued that the British now had a person 'never as yet afforded of conversing unreservedly and without the aid of interpreters, with those who influence the emperor's councils' (Staunton Letters, London, 20 November 1809). This person, he continued, was familiar with 'the modes of acting and thinking peculiar to the Chinese' and would enable a British ambassador to 'enter into confidential communications on subjects of mutual interests of both empires ... it will not be too much to expect the most important and beneficial results from his negotiations' (Staunton Letters, London, 20 November 1809).

23 Known as the 'Neptune Affair'. For a concise summary, see Conner (2009, pp. 69-70).

24 See Morse (1926/1966, vol. 3, pp. 76-99) and Wood (1940) for a detailed account of the British occupation of Macao.

25 This is a formal letter written by Staunton to Charles Grant, the chairman of the Secret Committee of the East India Company, sent from his mother's house in Devonshire Street, London. The plan is written in a fine copperplate hand, suggesting that Staunton hired a professional scribe to offer the best presentation. 
Staunton's expectations of beneficial 'negotiations' at the Qing court represented an obvious misjudgement, if not ignorance, of Qing diplomacy and indicates strongly his belief that any future British embassy would be received outside the tribute system. This assumption, it will be seen, was accepted unquestionably by Barrow in his call for an embassy in 1815, based on his confidence in Staunton's ability to communicate directly in Mandarin to ensure success for British goals. Further, the Qing court, Staunton pointed out, favourably received foreign missions as 'Embassies bearing presents are not only gratifying to the personal vanity of the Sovereign, but [were] also useful politic exhibitions to the people' (Staunton Letters, London, 20 November 1809).

Staunton was confident that his plan would be approved and waited for confirmation that he would be appointed the next British ambassador to the Jiaqing emperor. Barrow sent a letter marked 'Most Secret' dated 10 November 1809, which read, 'We have done the deed: and I most heartily congratulate you on the almost certain prospect of your going to Pekin as the King's ambassador' (Staunton, 1856, p. 43). The Company Directors, however, approved the plan in theory, but thought it 'most advisable not to include any person who was actually in the service of the East India Company' (Staunton, 1856, p. 44). The appearance of Company men would indicate that this was a mission sent primarily for commercial purposes and not as a compliment from the British sovereign. Staunton was devastated. He wrote later in his memoirs:

It is impossible to express the mortification and irritation of mind which I felt at this most unlooked for communication; and I must say that now, coolly reflecting upon it, after a lapse of six-andthirty years, I still think I was extremely ill used. (1856, p. 44)

Plans for a new embassy were shelved by the Company by the end of 1810 and the idea was placed in abeyance.

\section{Staunton's Second Period at Canton, 1811-1816}

Staunton arrived back at Canton in January 1811 to resume his posting where he met the new viceroy, Sungyun, who was well known to the British, having escorted the Macartney Embassy from Peking to Canton 
in $1793 .{ }^{26}$ Macartney had praised Sungyun both for his 'strain of liberality scarcely to be expected in a Tartar or a Chinese' and for his 'most friendly and gentleman-like manner' (Cranmer-Byng, 1962, p. 178). Sungyun, on learning of Staunton's presence with the Company at Canton, 'Expressed himself surprised and much pleased that a person whom he well recollected with his Father in the British Embassy, happened to be at this time in China'. He also emphasised that he was 'very much the friend' of the British nation (Morse, 1926/1966, vol. 3, p. 169).

Staunton was invited, in a private capacity, to the viceroy's palace where conversation turned to Macartney. Staunton reminded the viceroy that it was time for another British embassy to the imperial court, but was quickly disabused of any such prospect. He was told in the firmest terms:

There is no occasion for you to send another Embassy to Pekin. The Emperor knows it is a long way, and does not wish you to trouble yourselves. Besides the Climate does not agree with you; you may catch infectious Distempers. No! Your Nation must not send an Embassy. I will not allow it. It is out of the Question and you must not think of it. (Morse, 1926/1966, vol. 3, p. 173)

Crucially, it appears that Staunton's letter to Barrow failed to pass on this critical piece of information but stressed instead the 'civilities that had passed between the Chinese and the British' and the gifts of silks, Chinaware and 'other small articles, of no great value in themselves, but considered as tokens of friendship' (Staunton Letters, Macao, 20 July 1811).

A further dinner at the viceroy's palace was held a week later. Staunton was accompanied by John Roberts, the president of the Select Committee. Several high-ranking mandarins were present, referred to as 'the Tsiangkun [Tartar-General] ... and the Hoppo' (Staunton Letters, Macao, 20 July 1811). ${ }^{27}$ Their intense scrutiny of the viceroy inhibited informality. Rather, the British were addressed on the importance of conforming to the laws and customs of China and with correct protocol. Staunton wrote:

At the end of the first conversation the Viceroy said 'As I have a great regard for you, you must allow me to shew you our Chinese customs, one of them is to bend the knee to great Mandarines,

26 Referred to as Sun-yün by Fu (1966). Fu added that Sungyun was aware of the cost of the Macartney Embassy to the Chinese treasury and 'the tension' it had caused in China (1966, vol. 2, p. 607 , fn. 141).

27 I have been unable to identify the Tartar-General concerned. 
pray let me see you perform that ceremony'. Though not a little surprised at such an address, I at first simply answered that I had the greatest respect for His Excellency, but was obliged to decline paying him the compliment he required, as our English customs forbab [sic] it. (Staunton as quoted in East India Records, BL IOR G/12/196 (Reel 1) F 171).

The British judged the viceroy's manner as a need to distance himself from them in front of the mandarins. He threatened an end of his personal friendship and insinuated also that he would close Company trade.

Viceroy Sungyun's emphasis on correct protocol offers some insight into the historical mystery associated with Macartney's reception before the Qianlong emperor; namely, did Macartney perform the kowtow as the Chinese claimed, or did he perform the British ceremony of bending one knee described by Sungyun ${ }^{28}$ Sungyun's reference to 'bending the knee' suggests he witnessed Macartney performing this ceremony at the Qianlong court and was demanding a repeat performance by Staunton as a matter of form required on such occasions. Staunton remained firm and displayed the tenacity shown subsequently during the Amherst Embassy. He reassured Sungyun that his actions represented no disrespect towards him, but were governed rather by English custom stipulating that the requested ceremony was reserved only for the king or foreign sovereigns (Staunton as quoted in East India Records, BL IOR G/12/196 (Reel 1) F 171). The British position on the ceremony was certainly clarified at this time and would have served to alert the Qing authorities that the kowtow would not be performed before the emperor. Whether such information was passed on to Peking resulting in forewarning the court is not known, but it certainly helps explain the mandarins' immediate focus on the kowtow after the arrival of the Amherst Embassy in Tianjin in 1816.

Despite these events, Staunton's unique and friendly relationship with Sungyun endured. Sungyun invited the British to nine conferences and entertainments during his tenure at Canton (Staunton, 1822, p. 135). Like the earlier visit of the viceroy to the British Factory in 1800, Sungyun made an unprecedented call on Staunton and the Select Committee at Macao and visited the British ships anchored at Whampoa where he was lavishly received by a 19-gun salute and enjoyed a 'splendid 
entertainment'. ${ }^{29}$ His visit was read as 'an extraordinary compliment' to the British and one never seen before in China (Staunton Letters, Canton, 15 November 1811). The Hoppo was also very accommodating at this time leading to British hopes of a 'more favourable opening' for improved relations between the Company and the Chinese. Staunton told Barrow:

These things are trifling in themselves, [but] are very unusual here, where the Mandarins are in general too proud and ignorant, to take any notice of foreigners except to give them trouble and inconvenience. (Staunton Letters, Macao, 20 July 1811)

Sungyun, unfortunately, was prematurely recalled by Peking after a period of only six months to take up a position as president of the Board of Civil Office (Eastberg, 2009, p. 164). Relations at Canton, Staunton commented disparagingly, 'immediately fell back into the old channel' (Staunton, 1856, p. 56). Staunton had received mixed messages regarding the propriety of sending another embassy. Sungyun's long-lasting friendship, forged at the time of Macartney, had ensured a thaw in the normal chilly relations between the Select Committee and the Chinese Government. But Staunton was warned in explicit and unofficial terms that sending another embassy would not be welcomed.

Staunton received permission to return to England in 1812 after a period of ill health. ${ }^{30}$ His arrival coincided with debate on the renewal of the Company's charter in the face of growing opposition to its monopoly of the tea trade from British free traders wishing to open trade with China. In consultations with the British Government, Staunton convinced Lord Buckinghamshire, President of the Board of Control, that a Company monopoly of the China tea trade was essential given the 'special circumstances ... arising out of the extraordinary system of the Chinese government' (Buckinghamshire to Staunton, 2 September 1812, as quoted in Staunton, 1856, p. 58). The renewal of the Company's charter in 1813 opened the India trade to private merchants, but the China tea monopoly, which henceforth became the Company's most lucrative and important asset, remained and had to be protected at all costs.

29 The British gave the viceroy clocks and watches, which he did not accept, as well as foreign tobacco, wine, perfume, and clothes. The viceroy gave away the wine to the interpreters and other servants in the escort. The viceroy's presents to the British were 'double the value' (Fu, 1966, vol. 1, p. 383).

30 Platt (2018, p. 156) mistakenly wrote that Staunton remained continuously in Canton from 1810 until the arrival of Amherst in 1816. 


\section{The Immediate Causes for the Calling of an Embassy to the Qing Court}

Company relations at Canton with the Hoppo and the viceroy were especially strained in the period between and 1813 and 1814 . The cause was the insolvency of several Hong merchants who had borrowed heavily on credit from American private traders. Bankruptcy was a serious offence in China and the Company was concerned that the co-Hong merchants would seek to raise funds to pay debts resulting in impositions on foreign trade (Sargent, 1907, p. 21). Further, the emperor issued an edict proposing the co-Hong merchants be disbanded and all Western trade be placed under more rigorous conditions and in the charge of its two richest merchants (Morse, 1926/1966, vol. 3, p. 194). ${ }^{31}$ The prospect of only two men controlling prices for exports and imports drew vehement opposition from the Select Committee who read the edict as an attempt to destroy all the privileges the Company had so far acquired. Charles Grant, the chairman of the Company Board of Directors, later reported to the House of Lords on the state of the China trade in 1821, 'Slender those privileges certainly are, but without them [the] trade would soon sink into absolute insignificance' (Charles Grant, 5 March 1821 as quoted in Report [relative to the trade with the East Indies and China] from the Select Committee of the House of Lords, 11 April 1821, p. 172). Staunton agreed. In his view, the placing of the trade in the hands of only one or two merchants was the equivalent of 'shutting up the port' (Staunton, 1822, p. 297). The Select Committee succeeded in having the proposal quashed.

Matters were not improved with the arrival of a new Hoppo in 1813 whose character towards the British was described as 'boorish' and 'overbearing' (Morse, 1926/1966, vol. 3, p. 197). A stickler for correct procedure on

31 These were Howqua (Wu Bingjian) and Kowqua (unidentified). Fu (1966, vol. 2, p. 605, fn. 126) commented that the British preferred to trade with the less prosperous merchants because they could lend money to them at a very high rate of interest. Staunton, in fact, proposed to his father very early in his career at Canton that money be sent out in order to lend it to Chinese Hong merchants at a high rate of interest, namely, 18 per cent. This, Staunton suggested, was a way to make 'an honourable fortune'. He added that it was possible 'to take advantage of these schemes when you are junior in the Company'. At a senior level, he continued, 'you expose the merchant to suspicion of favouring support to the detriment of the Company's interest' (Staunton Letters, Macao, 20 April 1801). In September 1814, Staunton referenced that he remitted bills in 1813 'totalling $£ 5087.10$ ', adding, 'the Chinese merchants are paying off their debts at a good rate'. It is not clear if this statement refers to personal loans he may have made, or to the general state of affairs at Canton (Staunton Letters, Macao, 22 September 1814). 
all trade matters, the Hoppo prohibited direct communication with the Company and ordered that all reports be directed through the linguists (Morse, 1926/1966, vol. 3, p. 197). The Select Committee was alarmed by his attitude and reported that 'we must expect every possible annoyance and disruption which must necessarily arise from his rapacious Disposition' (Morse, 1926/1966, vol. 3, p. 197).

A most serious dispute at this time followed the actions of a British man-of-war, HMS Doris, during the 1814 trading season at the time of the Anglo-American War (1812-1814). The Doris had engaged 'in a very active blockade' of American shipping in Chinese territorial waters and illegally brought a captured American ship into the Pearl River. The viceroy informed the President of Select Committee, John Elphinstone, that:

\begin{abstract}
When two small countries [Great Britain and the United States] have petty quarrels overseas, the Celestial Empire is not concerned with them. However, when their ships enter territorial waters of the Interior [the Pearl River], they must obey and respect the prohibitions of the Celestial Empire ... If [Elphinstone] dares to disobey us, then not only shall we destroy their warships, but we shall also suspend their trade. (Fu, 1966, vol. 1, p. 394)
\end{abstract}

The Select Committee was instructed by the viceroy to order the departure of the Doris from China. On being informed that the Company held no authority over a ship of the Royal Navy, the viceroy threatened not only to use force against the Doris, but also proceeded to implement a series of raids on the British Factory. John Francis Davis wrote later:

The Chinese ... entered upon a course of aggressive measures not
against the frigate, but against the Factory, which soon became
intolerable. The local government first prohibited the employment
of native servants; they then sent persons to enter the Factory,
and seize upon such Chinese as they found there. The boats of
the Indiamen were molested while peacefully proceeding on their
business on the river; and every attempt was made to prevent
communication with our men-of-war. $(1836 / 1851 \text {, vol. } 1 \text {, p. } 72)^{32}$

32 John Francis Davis was the eldest son of Samuel Davis, a director of the Company. Following precedence given to the sons of notable members of the Company, Davis arrived at Canton in 1813 as a junior writer with the Company. He was appointed governor of Hong Kong from 1844 to 1848. 
A Chinese linguist, Ayew (Li Huaiyuan), based at the Factory was arrested at this time and sent to 'Tartary' (Xinjiang) in retaliation for the actions of the Doris. ${ }^{33}$ His treatment at the hands of the Chinese authorities as well as the unauthorised entry of the Chinese in the British Factory were the immediate catalysts for the decision to send the Amherst Embassy. Staunton wrote:

It may be observed that intrusion [into the Factory] is a very light term for the entry without notice or cause assigned of a police officer with his retinue, into a residence immediately distinguished by the national flag, and hitherto considered by foreigners as an inviolable sanctuary. If the inviolability of the British Factory were not maintained-what would become of the security of other foreign residences of less distinction and pretensions? (Staunton, 1822, p. 298)

The consequences of a Chinese attempt to place further restrictions on the activities of the Select Committee, the actions of the Doris, the raid on the British Factory and the arrest of Ayew had serious repercussions for Anglo-Chinese relations. Staunton, who was returning to China from England, had little idea of the turmoil he would confront. He wrote to his mother from the Anjere Roads in the Sunda Straits:

My thoughts are now chiefly directed towards China, where I am in some degree, at home, and shall not be long to arrive. I understand everything was quiet there when the last accounts came away, and that Mr. Elphinstone's management of the Company's affairs continue to give great satisfaction. (Staunton Letters, Anjere Roads, Straits of Sunda, 14 August 1814, italics in original)

His last term in China, however, proved to be 'by far the most active and anxious I passed in that country' (Staunton, 1856, p. 61).

33 Chinese treatment of Ayew, a Factory linguist, was a specific concern of the Select Committee. Ayew had been assigned with the task of carrying a letter and presents to Sungyun sent by the president of the Board of Control and the directors of the Company in 1812 to thank him for his assistance during the Macartney Embassy and more recently at Canton, but he was arrested at Peking and charged with illegally bringing gifts from Westerners to Chinese officials. He was allowed to return to Canton and resume work at the British Factory. An article on this question was published in 2014 in Chinese in The Journal of Chinese Studies by Lawrence Wang-chi Wong under the translated title "The 1814 "Ayew incident": Linguists in Sino-British relations in the nineteenth century'. 
Staunton was called on immediately after his arrival at Macao in 1814 as the committee's sole negotiator with the Chinese authorities in the Doris dispute. ${ }^{34} \mathrm{He}$ briefed Barrow in a private letter and informed his mother that he was 'up to his head and ears in Discussions with the Chinese government' (Staunton Letters, Macao, 14 October 1814). While welcoming the opportunity to renew his acquaintance with 'the language and customs of this people', he refused absolutely to submit to the viceroy's demands (Staunton Letters, Canton, 14 December 1814). After an anxious month of fruitless and tedious negotiations with 'Mandarins of rank at the Factory' over the actions of British warships in Chinese territorial waters, Staunton took the initiative. Declaring the Select Committee had no control over the actions of the Royal Navy, Staunton took the unprecedented and tough decision to suspend trade and ordered all British subjects and ships to leave Canton (Fu, 1966, vol. 2, p. 612). Staunton wrote:

I was compelled to break off the negotiation, to strike the British flag, and to retire with the whole body of British subjects from Canton; and that it was only when our ships [those already at Whampoa] were upon the point of sailing through the Bocca Tigris, and thus finally quitting the port, that I was overtaken by such a conciliatory overture from the Viceroy as warranted me in returning to Canton and renewing the negotiation. (1856, p. 63)

His strategy worked. The viceroy backed down, the ships were loaded and trade resumed. Staunton's firm stand against Qing officialdom set a precedent for Amherst's actions during the Amherst Embassy's future negotiations with the mandarins. '[My] only weapon[s]', Staunton (1856) recalled, 'were those of argument and an appeal to the universal principles of justice, forcibly addressed to the Chinese in their native language, though in a spirit of British independence' (p. 64), which had won the day.

Staunton's actions, significantly, brought an immediate rebuke from the Jiaqing emperor who issued an edict dated 8 January 1815:

There is an English barbarian, Ssu-tang-tung [Staunton], who previously came to the Imperial capital at the time his country presented tribute, was young and crafty, and throughout his return journey drew maps of all strategic spots of the mountains and rivers ... he passed through. After he arrived at Canton he did not return 
to his native country, but has lived in Macao for twenty years. He understands Chinese ... Barbarians who come to Kwang-tung [Canton] ask his advice and follow his suggestions. Probably in the long run he will make trouble. (Fu, 1966, vol. 1, p. 394). ${ }^{35}$

A further edict concerning the actions of British warships was issued a couple of days later:

Recently, the escorting warships of England, disobeying the established regulations that foreign ships must anchor outside our territorial sea, sailed into the Boque Fortress. Such deceit is unimaginable ... Hereafter, the escorting warships of various nations should continue to obey the established regulations against entering our territorial waters ... If they dare to enter our defensive zone, we should consider firing our cannon to scare them away so that they may clearly understand that they will have to deal with us. (Fu, 1966, vol. 1, p. 395)

Staunton was not the only Englishman to come under imperial suspicion at this time. In 1807, the Reverend Doctor Robert Morrison of the London Missionary Society arrived at Canton. ${ }^{36}$ Destined to be the senior interpreter for the Amherst Embassy, his proficiency in Mandarin ensured his appointment in the same capacity with the Company. Morrison also engaged in the illegal activities of teaching Mandarin to Company personal at the British Factory and compiling a Chinese-English dictionary sponsored by the Company. ${ }^{37}$ His major pursuit involved the translation of Christian texts into Chinese, which he printed illegally at Macao. This was in defiance of the Jiaqing emperor's imperial edict of 1805 that specifically prohibited books printed in the 'Chinese and Tartar

35 The edict reveals the Qing court's misinformation about Staunton that had repercussions later during negotiations between the British and Chinese at the time of the Amherst Embassy.

36 Morrison was the first Protestant missionary to arrive in China. He landed at Canton in 1807 on an American ship (as Company ships were forbidden to carry missionaries) and hoped to spread the gospel in China. Morrison first stayed in two small rooms at the American Factory where he went 'native', 'adopting the habits and ... dress of the natives' and eating Chinese food (see Morrison, 1839, pp. 187-188). Staunton had received a letter of introduction about Morrison from Sir Joseph Banks and became his 'friend and advocate' at Canton (Staunton, 1856, p. 36). Staunton recommended Morrison to John Roberts, the president of the Select Committee, and he was hired as a translator with the Company in 1809 with a salary of $£ 200$. He set out to work on a Chinese translation of $A$ grammar of the Chinese language (1815), A dictionary of the Chinese language (1815) and the Scriptures (Morrison, 1839, pp. 239-240).

37 Morrison's skill in Chinese was acknowledged by Staunton who wrote, 'I was certainly several years prior to him in [studying Mandarin] but I cultivated the Chinese language altogether for different purposes, and much less exclusively and assiduously than he did [and] I ... with pleasure, acknowledge that he attained ultimately to a much greater degree of proficiency' (1856, p. 37). 
languages' as these were viewed as attempts to 'facilitate the propagation of [European] tenets' (Barrow, 1810, fn. 304). His actions brought him to the notice of the Chinese authorities who, in 1815, conducted a raid on his office, destroying his printing press and arresting a Chinese employee (Staunton, 1856, p. 37). Morrison acknowledged, 'The present state of China is such as renders printing, and several other labours very difficult; and even personal residence uncertain' (Morrison, 1839, p. 385). Thus, Morrison and Staunton, both men destined to play a major role in the Amherst Embassy, had aroused Chinese Government suspicion on the eve of the embassy's arrival..$^{38}$ Informing British assessments of the Jiaqing emperor was his recent escape from an assassination attempt in 1813 which, in Morrison's view, contributed to the emperor's suspicion of Staunton. Morrison informed Staunton in 1815 that the emperor was:

Immured in his palace, distrustful of all around him; a large number of persons denounced as rebel leaders not yet taken; he supposes that plans against his life and throne are carrying on, and may burst forth suddenly, as the last convulsion did. In this state of mind some designing villain brings your name before him, says that you took maps of the country twenty years ago; that the encroachments of the English bringing ships of war, bringing troops, entering the river, and attacking the people of other countries, \&c., were acts all committed by your instigation! What then must His Majesty have thought with his fears already so much excited? (Morrison to Staunton, 10 January 1815, in Morrison, 1839, p. 425)

The loss of mutual trust between the British and Peking also extended to the Select Committee and the Chinese Government at Canton. The British blamed this, in part, on the obstreperous behaviour of the viceroy. Davis, writing in 1836, explained:

The conduct and disposition of the Chinese government for some time past had been such, as to prove that the commercial interests of [Great Britain] in China were exposed to the utmost hazard from the chance of perpetual interruption at the will of a capricious and despotic set of delegates, who kept the court of Peking in profound ignorance of their own oppressive and arbitrary conduct towards the Company's trade. (1836/1851, vol. 1, p. 73)

38 Morrison informed the Select Committee of the 'personal hazard' and 'feeling an apprehension that writing or translating a Letter to His Majesty the Emperor of China, which will of course contain an impeachment of the local Government of this Province, will subject me to personal suffering from the Chinese even long after the present difference shall be arranged' (Morse, 1926/1966, vol. 3, p. 211). 
He added:

To these circumstances are to be attributed the Embassy of Lord Amherst in $1816 \ldots$ which object was to secure, if possible, the commerce of Great Britain upon a solid and equitable footing under the cognizance of the emperor, and with the advantage of a ready appeal to him in case of need. (1836/1851, vol. 1, p. 73)

The Jiaqing emperor, the British assumed, was kept in ignorance of the true state of affairs of trade at Canton. His intervention, it was thought, would follow a direct official approach on behalf of the British sovereign and would serve to place trade on a secure and stable basis. But the fact that Staunton and Morrison, both men destined to play a vital role in Lord Amherst's Embassy, were regarded with the utmost suspicion by the Chinese authorities, did not augur well for their reception at the Qing court. Further, British military intervention at Macao in 1808 as well as the 'agitated' state of affairs in Shandong province, where a rebellion had resulted in the death of 20 court eunuchs on orders of the emperor, hardly disposed the imperial court to welcome meddlesome foreigners (Morrison's journal entry, 7 November 1813, as quoted in Morrison, 1839, p. 373). Historians, principally Wengsheng Wang, note a hardening of the Qing attitude towards the British who were now regarded as the most troublesome 'of all Westerners' with a voracious appetite for trade (Wang, 2014, p. 248). This change, in Wang's view, partly explains the 'emperor's rejection of the Amherst Embassy in 1816' (2014, p. 248). Further, rumours circulating at Macao of the British occupation of Washington in 1814 during the Anglo-American War heightened local suspicion of the British. Staunton commented on a 'ridiculous report' that 'the British who had recently landed in America, and destroyed the city of Washington, were destined ultimately for the coast of China, upon some similar service' (1822, p. 138). He added:

There is great reason to believe that [the act of the Doris], together with the frequent cruizing of our ships of war on their coasts, was considered by the Chinese, not merely as a national affront, but as actually connected with some ulterior schemes for a hostile invasion of their territory. (p. 138)

Staunton first learned that an embassy was being contemplated in a personal letter from Barrow, dated 10 April 1815, which he received in September 1815. His reaction was far from enthusiastic. Another embassy, in his personal view: 
Is ... a measure about which $I$ have for some time ceased to be at all anxious and am so much aware of the risk of bad management, that I rather wish upon the whole that it might be abandoned. If however it is otherwise determined, it will of course command my best exertions and services. Whenever anything is settled, I trust due notice will be given us here, that we may be prepared accordingly. (Staunton Letters, Macao, 21 September 1815)

He hoped that an embassy would not damage Britain's reputation or cause it to:

Recede from that high and honourable position which our commercial representatives had taken at Canton, as well as our former diplomatic representative, Lord Macartney, had taken at Pekin. (Staunton, 1856, p. 66)

The possibility of another embassy to the Qing court and the prospect of playing a leading role in such a major diplomatic initiative in AngloChinese relations had long sustained Staunton's ambitions for recognition and fame beyond the accumulation of wealth as a Company servant in Canton. It is ironic that, at a time when Staunton's enthusiasm for such an enterprise had largely evaporated, his friend and mentor in London, John Barrow, would seize the opportunity presented by events at Canton, based largely on Staunton's earlier reporting, to argue successfully for an embassy as the best means to address the parlous state of the Company's relations with the local authorities in China.

Barrow's strong advocacy of an embassy took place entirely in London without further reference to Company representatives in Canton. Focus falls next on the events in Whitehall and Company headquarters in Leadenhall Street in connection with the decision to dispatch a special mission led by Lord William Pitt Amherst to the Chinese empire. 
This text is taken from Britain's Second Embassy to China: Lord Amherst's 'Special Mission' to the Jiaqing Emperor in 1816, by Caroline Stevenson, published 2021 by ANU Press, The Australian National University,

Canberra, Australia.

doi.org/10.22459/BSEC.2020.03 